\title{
The potential for birds to disperse the seeds of Acacia cyclops, an invasive alien plant in South Africa
}

\author{
THABISO M. MOKOTJOMELA, ${ }^{1{ }^{* \dagger}}$ JOHN H. HOFFMANN ${ }^{1}$ \& COLLEEN T. DOWNS ${ }^{2}$ \\ ${ }^{1}$ Department of Biological Sciences, University of Cape Town, Private Bag X3, Rondebosch 7701, South Africa \\ ${ }^{2}$ DST-NRF Centre for Invasion Biology, School of Life Sciences, University of KwaZulu-Natal, Scottsville 3209 , \\ Pietermaritzburg, South Africa
}

\begin{abstract}
Rooikrans Acacia cyclops is an aggressive invasive tree that threatens natural resources in South Africa. The seeds of $A$. cyclops have a prominent aril which attracts birds that ingest the seeds and disperse them endozoochorously. Two biological control agents, a Seed Weevil Melanterius servulus and a Flower-galling Midge Dasineura dielsi, were released on A. cyclops in 1991 and 2002, respectively. Together these agents have substantially reduced seed production and generally far lower numbers of seeds are now available to birds. A consequence of this transition from historically bounteous quantities of seeds to scanty seed availability is that birds may no longer associate with the trees and seed dispersal may be disproportionately reduced. To assess whether this has happened, seed attrition was measured by comparing the amount of seeds that disappeared from two groups of branches, one available to birds and the other enclosed in bird netting. Other types of granivores (mainly field mice) were excluded from both groups of branches with a plastic funnel placed around the stems. Mature seeds were also harvested and fed to caged bird species to determine gut retention times and germination rates of ingested seeds. Attrition rates of seeds showed that birds continue to remove seeds but that only a proportion of the crop is taken. Only two frugivorous species (Knysna Turaco Tauraco corythaix and Red-winged Starling Onychognathus morio) and two granivorous species (Red-eyed Dove Streptopelia semitorquata and Laughing Dove Streptopelia sengalensis) ingested $A$. cyclops seeds during feeding trials. Ingestion by birds enhanced seed germination except for those ingested by Laughing Doves. There were no apparent effects of length of gut passage time and avian body size on seed germination rates. Despite the diminished seed resource due to biological control agents, birds continue to disperse $A$. cyclops seeds.
\end{abstract}

Keywords: bird, dispersal distance, germination rate, gut-passage time, invasive trees.

The contribution that dispersers make to the future reproduction of plants is determined by two components, the product of quantity (number) and quality (probability of becoming a new adult plant) of seeds dispersed (Schupp 1993, Traveset et al. 2001, Schupp et al. 2010). Many studies

\footnotetext{
${ }^{\dagger}$ Present address: Global Change and Sustainability Research Institute, University of the Witwatersrand, Private Bag 3, Wits 2050, Johannesburg, South Africa.

*Corresponding author.

Emails: thabiso.mokotjomela@wits.ac.za, mokotjomelat@yahoo. co.uk
}

indicate that quantity, rather than quality, is more influential in seed dispersal effectiveness (Schupp 1993). At present there is a limited understanding of seed dispersal effectiveness in general (Wang \& Smith 2002, Nathan 2007, Mokotjomela 2012), with only one thorough study undertaken to date that focused on Australian tropical forests (Dennis \& Westcott 2006).

Birds are important dispersers of seeds (Howe \& Smallwood 1982, Jordano 2000, Schupp et al. 2010), with seed mortality and dispersal distances both likely to be influenced by gut passage time in birds (Nathan 2007, Schurr et al. 2009, Tsoar 
et al. 2011, Mokotjomela et al. 2013a). Benefits of avian endozoochory include dormancy release and enhanced germination (Howe \& Smallwood 1982, Schupp et al. 2010), especially where there is vector-specificity (Traveset et al. 2001). Although germination may be enhanced by passage through a bird's gut, it may also remain unchanged or even be suppressed (Traveset 1998, LaFleur et al. 2009, Jordaan et al. 2011, Mokotjomela 2012, Chama et al. 2013). Movement over long distances influences dispersal quality by reducing intraspecific competition and seed predation, which are generally higher close to the source (Howe \& Smallwood 1982), by opening genetic links between disconnected plant communities (Van Der Pijl 1982, Nathan et al. 2008, Schurr et al. 2009, Schupp et al. 2010) and by facilitating the formation of new self-sustaining populations in different landscapes (Sakai et al. 2001, Nathan et al. 2008).

Although some aspects of avian seed dispersal have been studied thoroughly (Knight 1988, Cowling et al. 1997, Jordaan et al. 2011, Mokotjomela et al. 2013a), quantifying patterns of seed dispersal distances remains a challenge (Nathan 2001, Schurr et al. 2009). A traditional seedcentred approach to understanding dispersal has inferred dispersal distances from fruit/seed morphology and the potential pool of consumers (Higgins et al. 2003), with more recent studies continuing to emphasize seed recovery location as the only means of determining seed dispersal distances (e.g. Scott \& Batchelor 2014). This approach provides limited understanding of rare long-distance dispersal events when compared with a contemporary vector-based approach that utilizes vector characteristics and behaviour to determine seed dispersal distances (Nathan et al. 2008, Schurr et al. 2009, Tsoar et al. 2011). A main assumption with this approach is that dispersal distance is positively correlated with the body size of a vector (Schurr et al. 2009, Tsoar et al. 2011, Mokotjomela et al. 2013a). However, dispersal distances are also influenced by spatial distributions of fruit or seed resources (Mokotjomela et al. 2013a).

Knowledge of bird-mediated seed dispersal can help in predicting future plant distribution ranges (Nathan et al. 2008, Tsoar et al. 2011, Mokotjomela et al. 2013a), and in screening the potential invasiveness of both established and emerging alien plants (Tucker \& Richardson 1995, Nel et al. 2004). This is certainly pertinent in the South
African Mediterranean climate region, where invasive alien trees constitute a major threat to native plant communities (Richardson et al. 1992). Predominant among these invasive trees are several Australian Acacia species which have been targeted with biological control using insect herbivores that destroy the flowers or developing seeds (Impson et al. 2011). One of these is Acacia cyclops, which now has two biological control agents in South Africa, a Seed Weevil Melanterius servulus and a Flower-galling Fly Dasineura dielsi, both of which substantially reduce overall levels of seed production (Impson et al. 2009, 2011, Moran et al. 2013).

Birds have historically been implicated as major dispersal vectors driving the invasion of $A$. cyclops in South Africa (Glyphis et al. 1981, Knight 1988, Underhill \& Hofmeyr 2007, Mokotjomela \& Hoffmann 2013). Of the approximately 70 Australian Acacia species that have been introduced into South Africa, predominantly during the 19th century, at least 13 are recognized as invasive (Henderson 2001, Richardson et al. 2011, Van Wilgen et al. 2011). Acacia cyclops was introduced into southern Africa in 1835, primarily for stabilization of sand dunes in the southwestern Cape (Shaughnessy 1980). It has since successfully naturalized and invaded coastal regions across the southern Cape (Henderson 2001). The proliferation of $A$. cyclops is ascribed to its widespread propagation as a source of fuel wood for domestic and small-scale commercial purposes (Richardson et al. 2011, Van Wilgen et al. 2011) and to its prolific seed production (Milton \& Hall 1981, Impson et al. 2009). Each seed has a prominent reddish-orange aril that attracts vertebrates, especially birds, which consume and pass the indigestible seeds, thereby enhancing the spread of the plant (Glyphis et al. 1981, Underhill \& Hofmeyr 2007, Mokotjomela \& Hoffmann 2013). The seeds are also buried in accumulations by ants (Holmes 1990) and possibly seed-hoarding rodents (Midgley \& Anderson 2005, Rusch 2011).

Among the bird species documented as feeding on the seeds of $A$. cyclops (Glyphis et al. 1981), at least one, the Red-winged Starling Onychognathus morio, has been shown to enhance seed germination rates (Impson 2005). Impson (2005) also demonstrated that while high levels of feeding damage by the native alydid bugs Zubulius spp. reduced seed viability, moderate levels of damage increased germination rates of seeds ingested and 
passed by birds. Nevertheless, the impact of other factors, such as microbes and arthropods, on seed viability and germination rates has generally been overlooked in studies investigating endozoochorous seed dispersal (Fricke et al. 2013).

The aim of this study was to assess whether birds continue to consume seeds of $A$. cyclops at high levels in plant populations when seed production is both curbed and erratic due to biological control. We predicted that seed removal by birds might be diminished because birds generally display reduced levels of activity in trees with small fruit/seed crop sizes (Saracco et al. 2005, Mokotjomela et al. 2013b). We also assessed how the body size of potential vectors influenced seed germination and dispersal distances to confirm that seed retention times are positively correlated with body size in birds (Nathan 2007, Schurr et al. 2009).

\section{METHODS}

\section{Study sites}

Seed removal and deposition by birds were measured and seeds were harvested at Koeberg Nature Reserve (33⒋ $\left.30^{\prime} 32.97^{\prime \prime} \mathrm{S}, 1^{\circ} 26^{\prime} 29.45^{\prime \prime} \mathrm{E}\right)$ and at Langebaanweg $\left(32^{\circ} 57^{\prime} 27.63^{\prime \prime} \mathrm{S}, 18^{\circ} 06^{\prime} 47.18^{\prime \prime} \mathrm{E}\right)$, situated c. $120 \mathrm{~km}$ apart in the southwestern Cape of South Africa. The two study sites are located in the Cape Floral Region, a globally important centre of plant diversity (Cowling et al. 1995). The climate of the Cape Floral Region is Mediterranean, with $75 \%$ of rain falling between April and September (the austral winter). Rainfall varies markedly with topography: $300-500 \mathrm{~mm}$ in the lowlands and $1000-3300 \mathrm{~mm}$ in the mountains, where clouds and fog can persist for long periods and there is frequent snowfall in winter (Cowling et al.1995). Winters are mild but summer days are hot and dry, with morning fog a common occurrence in the coastal areas.

\section{Seed removal and deposition by birds}

To measure seed removal by birds, two seedbearing branches of approximately equal size $(2.2 \pm 0.4 \mathrm{~cm}$ stem diameter) were tagged on each of 10 trees at each study site. One branch of each pair was covered with bird netting to prevent birds from accessing seeds and the other was left uncovered. Mice were excluded from the branches by securing downwardly directed funnels made from cool drink (soda) bottles around the proximal portion of the stem. All branches were chosen on trees of approximately equal height: $4.1 \pm 0.3 \mathrm{~m}$ (mean \pm se) at Koeberg Nature Reserve and $5.6 \pm 0.3 \mathrm{~m}$ at Langebaanweg. Total seed production on each tagged branch was calculated by counting the number of seed-bearing pods and multiplying this value by the average number of seeds per pod $(8.7 \pm 0.4$ seeds). Seed removal was monitored at monthly intervals by counting seeds that had been removed from the open pods during the entire period of seed availability (December 2012 to July 2013).

Seed deposition by birds was measured in 10 traps made from plastic trays with a surface area of $1 \mathrm{~m}^{2}$ and $60-\mathrm{mm}$ depth placed beneath the canopies of each tree. The tops of the traps were covered with 5 -mm-diameter wire mesh to stop removal of seeds from the traps by rodents. The seed traps were emptied at monthly intervals, when counts of fallen seeds and seeds deposited by birds were recorded for the entire period of seed production. Recognizably arilate seeds constituted the portion of fallen seeds and seeds without arils represented those that had been deposited by birds in faecal or regurgitated pellets.

\section{Feeding trials and germination tests}

Bird species were obtained either by live-trapping in walk-in traps baited with fruits and millet seeds or by using captive birds kept in aviaries at the School of Life Sciences, University of KwaZuluNatal, Pietermaritzburg. Ten native bird species were used in the feeding trials. The natural ranges of six of these overlapped with $A$. cyclops, including the five frugivores: Knysna Turaco Tauraco corythaix $(n=4)$, Red-winged Starling Onychognathus morio $(n=4)$, Rock Dove Columba livia $(n=4)$, Speckled Mousebird Colius striatus $(n=2)$ and Cape White-eye Zosterops virens $(n=6) ;$ and three granivores: Red-eyed Dove Streptopelia semitorquata $(n=5)$, Laughing Dove Streptopelia sengalensis $(n=8)$ and Southern Red Bishop Euplectes orix $(n=6)$. Most of these bird species are known seed consumers and potential seed dispersers (Hockey et al. 2005, Rogers \& Chown 2014). The other two granivorous species were Fan-tailed Widowbird Euplectes axillaris $(n=9)$, which is distributed across parts of the country where $A$. cyclops does not occur, and the non-native Zebra Finch Taeniopygia guttata 
$(n=6)$. This range of bird species was expected to be sufficient to elucidate any effect of variation in body size on seed germination rates and gut passage times (Jordano 2000, Nathan 2007, Schupp et al. 2010).

At the start of the feeding trials each of the birds was weighed in a nylon bag on a spring balance and then transferred to one of the aviaries in the experimental rooms with controlled environmental conditions: of $25{ }^{\circ} \mathrm{C}$ temperature (day and night) and a photoperiod of $12 \mathrm{~h}$ (Jordaan et al. 2011). Aviaries were provided with perches and the birds were maintained on a commercial food mixture appropriate for their natural diet. Fresh water was supplied ad libitum.

Birds were kept overnight for at least $12 \mathrm{~h}$ for acclimation to experimental conditions before feeding trials started (Conour et al. 2006). At least 10-30 arilate seeds were presented to the different bird species in Petri dishes at the beginning of the experimental day (06:00 h). The birds were then observed for $4 \mathrm{~h}$ to assess how they processed and ingested the seeds, after which any remaining seeds were removed and the commercial maintenance diet was provided. Egested seeds were collected in newspaper-lined plastic trays placed beneath the aviaries. Seed egestion was monitored until the end of the experimental photoperiod at 18:00 h. For frugivores, seeds collected during each 30-min interval of the day were separated into two groups: regurgitated seeds, which were identifiable because they had remnants of aril still attached or included in the pellet, and defecated seeds, which had much less aril and were mixed with other faecal constituents and a white paste of uric acid. For the Redwinged Starling, which retained seeds overnight and released them after the first meal of the following day, an additional 'overnight' gut passage time group was recorded. For granivores, where seeds were only defecated, numbers of ingested seeds and the length of gut passage times were recorded. The gut passage time was estimated as the interval between first ingestion of seeds and the time at which the faeces with seeds was observed. We assumed that seeds ingested first would be either regurgitated or defecated first. For two frugivorous bird species, gut passage time estimation stopped after $4 \mathrm{~h}$ of monitoring feeding trials, whereas seed egestion for the two granivorous species was monitored until the end of the day.
Feeding trials with each species were repeated until at least 50 gut-passed seeds were gathered for subsequent germination trials. The number of egested seeds was recorded and the batches of seeds were kept in dry paper bags for germination rate tests in a greenhouse at the Department of Biological Science, University of Cape Town. Intact seeds were extracted from the faecal samples and regurgitated pellets. Batches $(n=50)$ of ingested and un-ingested seeds were sown separately into labelled $195 \times 60-\mathrm{mm}$ germination trays of $60-\mathrm{mm}$ depth. Each tray contained sterilized beach sand into which 10 seeds were buried in two rows of five seeds each. The 40 germination trays were irrigated each morning (at 09:00 h) by an automated irrigation system from the commencement (18 September 2013) to termination (15 January 2014) of the experiment. The numbers of seedlings that emerged in each germination tray were recorded at weekly intervals over the 16-week monitoring period and expressed as percentages of the numbers of seeds initially sown.

\section{Statistical analysis}

The study experimental design was balanced, with equal sampling intervals and number of branches across the season at each site. All data were normally distributed. Monthly seed removal rates from the tree canopy by birds were analysed using univariate general linear models (GLM-ANOVA), with the percentage removal rates fitted as the response variable and the study sites and months as fixed factors. A Bonferroni adjustment procedure was applied to distinguish significantly different monthly mean percentage seed removal rates by birds in SPSS version 22.0 (IBM Corp., Armonk, NY, USA).

A generalized linear model with Poisson errors was used to compare the number of seeds ingested by different bird species (SPSS version 22.0). A nonparametric Kruskal-Wallis $H$-test (STATISTICA version 11; Statsoft, Tulsa, OK, USA) was used to compare the gut passage times for seeds ingested by different bird species and a general regression model (GRM) was used to determine the association between gut passage time and body size of birds. Because Knysna Turaco and Red-winged Starling had more than one observed seed treatment type (e.g. defecation and regurgitation of seeds), differences in the impact of seed treatment type on germination rates were assessed using a 
GLM-ANOVA. All treatment categories were equally represented and normally distributed. Dunnett's post hoc test was applied to distinguish between significantly different means of germination rates of ingested seeds, the regurgitation seeds, as well as non-treated seeds in the experimental control. Means are presented \pm 1 se.

\section{RESULTS}

\section{Seed removal and deposition by birds}

Seed attrition rates were significantly greater on non-bagged branches at Langebaanweg (16.2 \pm 3.1 seeds) than at Koeberg $(9.2 \pm 2.0$ seeds; $\left.F_{1,278}=7.4, P=0.007\right)$. There were significant interactions between sites and treatments $\left(F_{1,276}=4.5, P<0.035\right)$, with greater numbers of seeds disappearing from the bagged branches at Langebaanweg than at Koeberg. Seed attrition rates were significantly greater on non-bagged branches than on bagged branches at Koeberg $\left(F_{1,126}=4.1, P=0.044\right.$; Fig. 1$)$, but not at Langebaanweg $\left(F_{1,126}=2.9, P=0.089\right.$; Fig. 1$)$. On the non-bagged branches, there were significant differences in the monthly attrition of seeds $\left(F_{6,125}=7.9, P<0.0001\right)$, with the greatest numbers of seeds disappearing during January at Koeberg and during June at Langebaanweg. Significantly greater numbers of both bird-deposited $\left(F_{1,138}=37.4, P<0.001\right.$; Fig. 2$)$ and naturally falling $\left(F_{2,125}=73.4, \quad P<0.0001\right.$; Fig. 2$)$ seeds were recorded at Langebaanweg than at Koeberg (Fig. 2).

\section{Feeding trials and germination tests}

Only four of the 10 bird species ingested A. cyclops seeds during the feeding trials: Knysna Turaco $(9.3 \pm 0.7$ seeds per bird), Red-winged Starling ( $8.1 \pm 0.7$ seeds per bird), Red-eyed Dove (6.6 \pm 0.6 seeds per bird) and Laughing Dove $(5.3 \pm 0.4$ seeds per bird). There were significant differences in the numbers of seeds ingested by different bird species (Wald $\chi_{3}^{2}=30.0$, $P<0.001)$. The Knysna Turaco ingested significantly greater numbers of seeds than the two dove species but not the Red-winged Starling (Wald $\chi_{1}^{2}$ $=1.3, P=0.223$ ). Cape White-eyes and Southern Red Bishops consumed portions of the arils from presented seeds, whereas the other bird species did not eat the seeds or arils. Approximately half
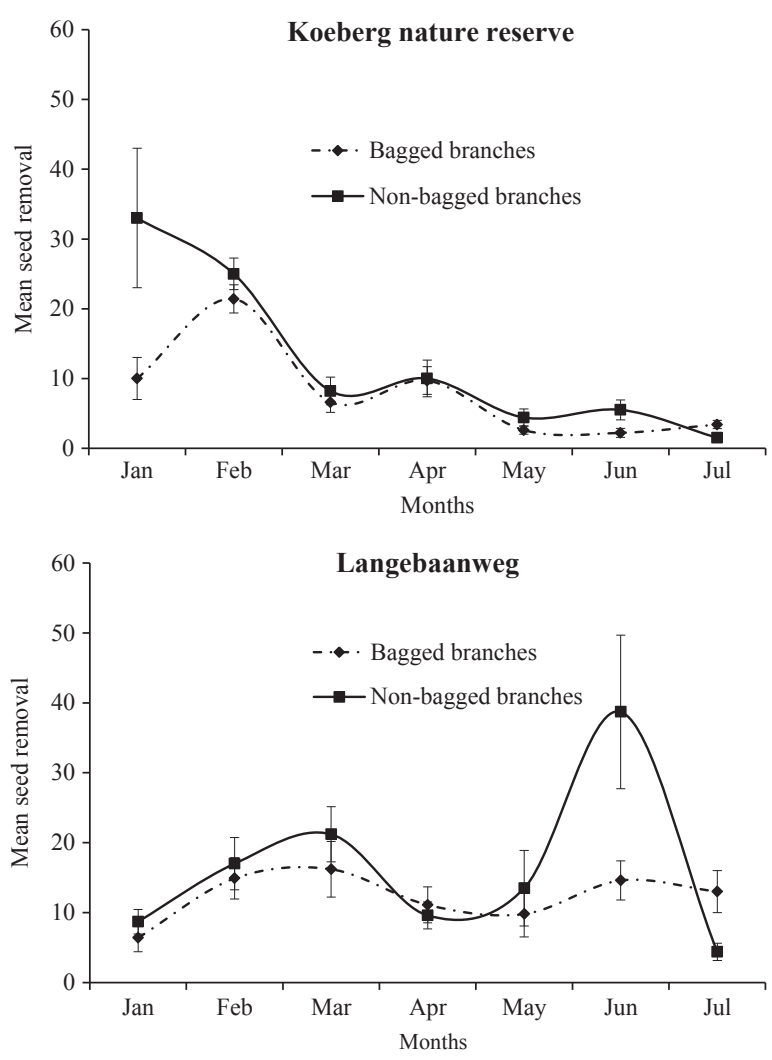

Figure 1. Removal of Acacia cyclops seeds in the tree canopy on branches exposed to birds (non-bagged) and branches from which birds and rodents were excluded (bagged) from December 2012 to July 2013 in the southwestern Cape, South Africa. Bars represent standard errors.

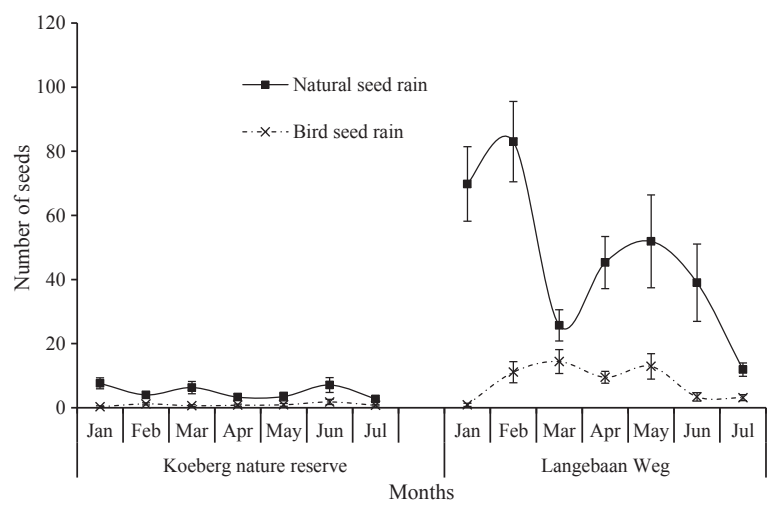

Figure 2. Monthly seed deposition by birds and natural seed fall measured in seed traps placed beneath the tree canopy at Koeberg Nature Reserve and Langebaanweg. Bars represent standard errors. 
the seeds ingested by Knysna Turaco and Redwinged Starling were regurgitated; the other half was defecated. The recognizable and identifiable seeds constituted $18.8 \pm 3.3 \%$ of the seeds ingested by doves (granviores) with no regurgitation. Seed passage times were significantly longer $\left(H_{3,87}=80.6 ; P<0.001\right)$ in the granivorous Redeyed Dove $(461.6 \pm 17.1 \mathrm{~min})$ and Laughing Dove $(340.5 \pm 28.6 \mathrm{~min})$ than in the frugivorous Knysna Turaco (110.4 $\pm 18.6 \mathrm{~min})$ and Redwinged Starling (35.0 $\pm 1.9 \mathrm{~min})$. There was no significant association between gut passage time and body size of birds $(R=0.16, P=0.261)$.

With the exception of Laughing Dove, seed that passed through the gut of the different bird species showed significantly higher germination rates than seed not first ingested $\left(F_{4,555}=4.0\right.$, $P=0.003$; Fig. 3). Dunnett's post hoc tests suggest that greater germination rates were recorded for seeds ingested by species in the following descending order: Red-eyed Dove, Red-winged Starling, Knysna Turaco. Overall, there were significant differences between the germination rates of the untreated, regurgitated and defecated seeds $\left(F_{7,552}=2.9, P=0.006\right)$, with higher germination rates in the defecated seeds (Fig. 3). However, germination rates of the defecated and regurgitated seeds were similar for the Knysna Turaco and Redwinged Starling. Furthermore, the length of seed passage times through the gut did not have a significant influence on germination rates, as seeds retained overnight by the Starling had similar
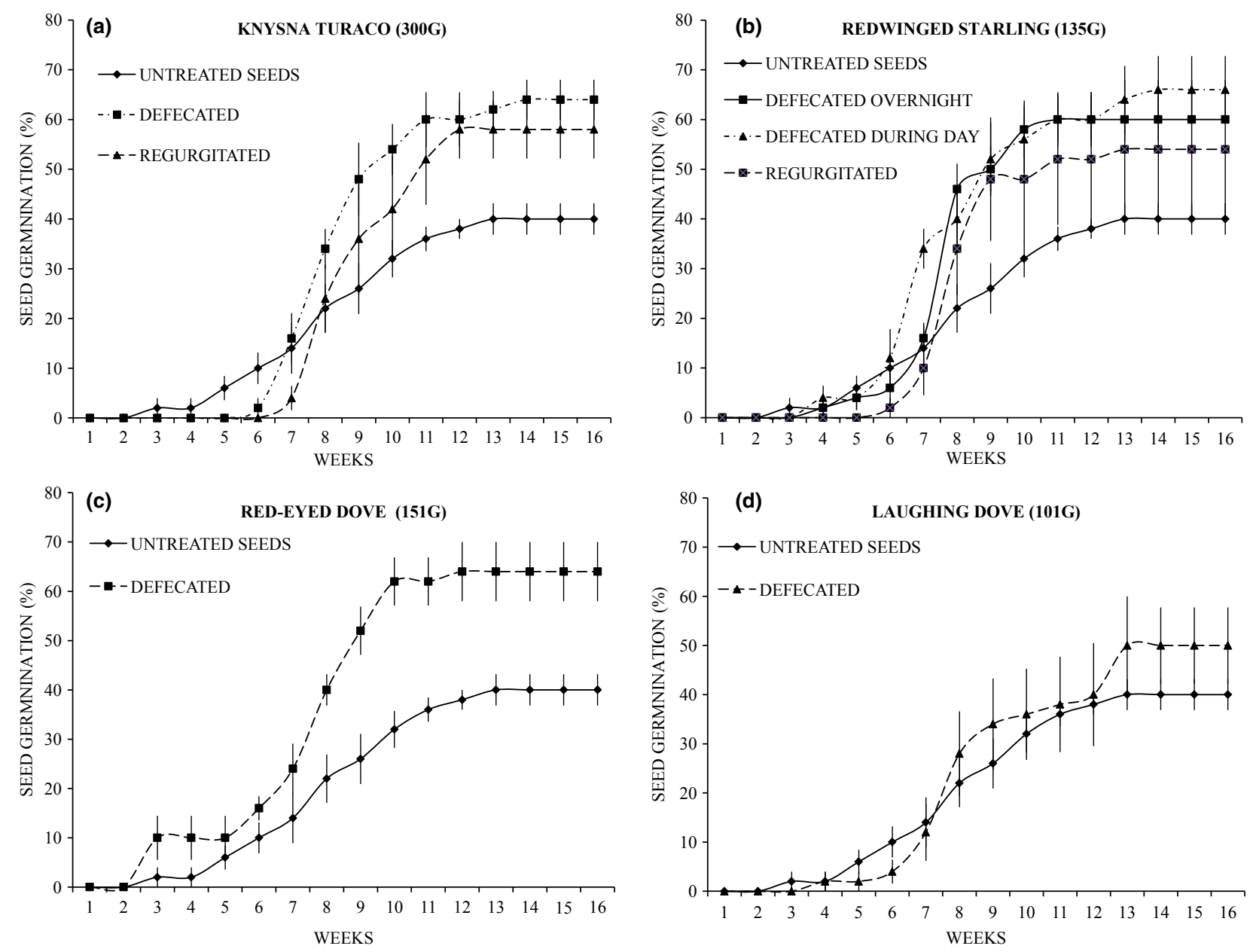

Figure 3. Cumulative germination (\%) over time for Acacia cyclops seeds ingested by different bird species: two frugivores, Knysna Turaco (a) and Red-winged Starling (b), and two granivores, Red-eyed Dove (c) and Laughing Dove (d). Bars represent standard errors. 
germination levels to those defecated by the other species (Fig. 3).

\section{DISCUSSION}

\section{Seed removal and deposition by birds}

The greater A. cyclops seed removal by birds at Langebaanweg than by those at Koeberg may be explained by differential annual seed production in both populations and the levels of seed damage caused by the Seed-feeding Weevil Melanterius servulus (Impson et al. 2009, 2011). Consistently during this study there was greater seed production at Langebaanweg than at Koeberg (relative seed deposition was $46 \pm 4.6$ and $4.9 \pm 0.6$ per $\mathrm{m}^{2}$, respectively), and this corroborates previous findings that large seed crops result in increased seed removal by birds (Blendinger et al. 2008, Mokotjomela et al. 2013b). Variation in seed attrition rates between the sites might also be influenced by relatively higher ambient temperatures at Langebaanweg (monthly range: $7.9-28.0^{\circ} \mathrm{C}$ ) that lead to more rapid abscission of seeds than at Koeberg, where temperatures were milder (monthly range: $10.0-23.1^{\circ} \mathrm{C}$ ) during the period of this study.

However, there were no substantial differences at either site in seed attrition from pods on branches exposed to birds compared with branches from which birds were excluded. The comparable rates of seed removal at Langebaanweg could be attributed to high levels of seed production, which has been reported to lead to reduced proportions of seeds removed due to seed predator satiation for A. cyclops (Holmes 1980). At Koeberg there may have been fewer seeds in the pods due to higher levels of damage by M. servulus (Impson et al. 2009, 2011), making the trees less rewarding as a seed source and therefore avoided by birds. Under these conditions, bird species feed predominantly on abscised seeds on the ground (Mokotjomela \& Hoffmann 2013). Indeed, studies have shown that plants with small seed crops (reduced by biological control in this case) might have a low probability of seed dispersal efficiency (Willson \& Whelan 1993, Murray \& Phillips 2010, Mokotjomela et al. 2013b).

The deposition of proportionately more seeds within thickets by birds at Langebaanweg than at Koeberg indicates that birds spend prolonged times foraging in A. cyclops thickets at Langebaanweg, which has been reported to result in localized seed deposition (Pratt \& Stiles 1983, Mokotjomela 2012). Furthermore, many birds might retain ingested seeds in the gut for relatively short times owing to the secondary metabolites that may act as a laxative (Cipollini \& Levey 1997) in the aril of $A$. cyclops, thereby limiting transport of seeds to more distant sites beyond the thicket. Therefore, given an equal disappearance of seeds from the non-bagged and bagged branches at each site, and localized deposition of ingested seeds, we suggest that birds might play a limited role in the seed dispersal of $A$. cyclops, especially in the presence of biological control agents in South Africa. This finding supports the prediction of the study that reduced seed production might limit foraging activity of birds and thus numbers of seeds dispersed. Therefore, suppression of seed production by biological control agents can indirectly enhance their effectiveness by lowering bird activity in thickets of $A$. cyclops.

\section{Feeding trials and germination tests}

The finding that only four of the 10 bird species ingested $A$. cyclops seeds is probably a result of the limited ability of small bird species to digest the extremely hard seeds (Tame 1992). It is also possible that certain bird species may have avoided the seeds because the arils have laxative effects, which disrupt nutrient assimilation in the gut (Cipollini \& Levey 1997, Lopez-Colleja \& Bozinovic 2000). Large amounts of aril were seen in regurgitated pellets of two frugivorous bird species. Red-eyed Doves fastidiously removed the aril before swallowing seeds. In addition, some birds might not consume the seeds of $A$. cyclops because they are indigestible. Indeed, birds possess well-established mechanisms for fruit/seed diet selection to maximize energy acquisition (Schaefer et al. 2003, Schaefer \& Schaefer 2006).

Studies have shown that passage of alien seeds through the gut of vertebrates frequently enhances germination (LaFleur et al. 2009, Mokotjomela 2012), which is important for determining the quality of seed dispersal by different vectors (Schupp 1993). Specifically, seeds that were defecated by Red-eyed Doves showed the highest germination rates, suggesting that seeds that survive grinding in the gut have a higher probability of germinating earlier. These germination results are accurate, as the quarantine greenhouse conditions were allowed to fluctuate with 
external environmental conditions even though the maximum temperatures recorded at Langebaanweg were not reached in the greenhouse. However, high ambient temperatures might have a limited effect on seed germination because birddispersed seeds are almost always deposited in ameliorated conditions under trees and shrubs in the South African fynbos (Manders \& Richardson 1992).

The rapid rates of germination observed in this study might result from scarification of the seeds in the muscular crops of granivorous bird species (Fritz et al. 2011). However, Laughing Dove was an exception in that germination of ingested seeds was not enhanced, probably due to the hardcoated $A$. cyclops seeds being resistant to scarification. This finding contrasts with a previous report that granivorous doves can grind all ingested seeds (Hulme \& Benkman 2002). In this study, doves also defecated $A$. cyclops seeds, consistent with the findings of Lambert (1989), who showed that a proportion of seeds ingested by doves survive and are passed intact. These findings might explain the observed high invasion rates of $A$. cyclops in South Africa, where the dove species are ubiquitous (Hockey et al. 2005).

Seed treatment is more limited in frugivorous birds, which can rapidly extract digestible material from fruits and disgorge less digestible parts within a short period of time (Jordano 2000, Charalambidou et al. 2003). Our results suggest that avian body size was not correlated with gut passage times of seeds and probably the impacts on seed germination rates. This is likely to be a consequence of different gut adaptations in frugivores and granivores (Stevens \& Hume 1998, Jordano 2000). The largest species that we studied, Knysna Turaco, which is also a frugivore, egested seeds more rapidly than the smaller granivorous dove species and this confounded the second study prediction.

Seeds defecated by frugivores were expected to undergo more seed cover scarification and corrosion, and so to display greater germination rates than regurgitated seeds. However, because both the defecated and regurgitated seeds showed equal germination rates for Knysna Turaco and Redwinged Starling, it seems that the testa of seeds of A. cyclops is resistant to scarification in the gut of frugivorous birds (Tame 1992). The extremely hard seed testa is also likely to account for non-significant differences in germination rates of seeds retained by Red-winged Starlings overnight as compared with short times during the day. A similar pattern was also observed in dove species, which retain seeds extensively in their elongate gut systems (Stevens \& Hume 1998). The greater germination rates of $A$. cyclops seeds that had passed through the gut of Red-winged Starlings in South Africa concur with the results of Impson (2005), and other studies reporting improved seed germination rates after passage through the gut of starlings (Spiegel \& Nathan 2007, LaFleur et al. 2009).

In conclusion, we show that removal of seeds of A. cyclops by birds was infrequent and that this is probably associated with the reduced levels of seed production due to the biological control agents. Prior to the inception of a biological control programme, seed abundance in A. cyclops was high. This was illustrated by Underhill and Hofmeyr (2007), who showed that the predominantly insectivorous Barn Swallow Hirundo rustica ingested many A. cyclops seeds. Indeed, limiting the number of seed dispersed by birds to pristine habitats might suppress both invasiveness and associate negative impacts of $A$. cyclops and other alien plant species with bird-dispersed seeds. Generally, ingestion of seeds by birds has varying impacts on germination rates (Traveset et al. 2001, Mokotjomela 2012, Mokotjomela et al. 2015) and our results are consistent with this premise. Contrary to previous studies, some seeds survived gut passage in the granivorous bird species, suggesting their potential to spread ingested seeds. Future research should focus on elucidating foraging spatial patterns of bird species that ingest seeds in order to understand potential seed dispersal distances across the landscape.

The National Research Foundation (NRF) and the University of Cape Town (URC) provided funding for this study. The University of KwaZulu-Natal, School of Life Sciences, Pietermaritzburg campus, provided the Animal House Facility of feeding trials, and the staff as well as student researchers assisted in experimental work. UKZN also provided animal use ethics clearance for the study. G. Greef and J. le Roux at Eskom are thanked for assisting in obtaining access to Koeberg Nature Reserve for field experiments. P. Haarhoff of the Fossil Park, Langebaanweg, is thanked for providing access to the study site. Tsepo Sefako and Toka Mokotjomela assisted in harvesting seeds in the field. We thank two anonymous reviewers, the Associate Editor and Rauri Bowie for comments that helped to improve this manuscript. 


\section{REFERENCES}

Blendinger, P.G., Loiselle, B.A. \& Blake, J.G. 2008. Crop size, plant aggregation, and microhabitat type affect fruit removal by birds from individual melastome plants in the Upper Amazon. Oecologia 158: 273-283.

Chama, L., Berens, D.G., Downs, C.T. \& Farwig, N. 2013. Do frugivores enhance germination success of plant species? An experimental approach. S. Afr. J. Bot. 88: 2327.

Charalambidou, I., Santamaria, L. \& Langevoord, O. 2003. Effect of ingestion by five avian dispersers on the retention time, retrieval and germination of Ruppia maritima seeds. Funct. Ecol. 17: 747-753.

Cipollini, M.L. \& Levey, D.J. 1997. Secondary metabolites of fleshy vertebrate-dispersed fruits: adaptive hypotheses and implications for seed dispersal. Am. Nat. 150: 346-372.

Conour, L., Murray, K. \& Brown, M. 2006. Preparation of animals for research - issues to consider for rodents and rabbits. ILAR J. 47: 283-293.

Cowling, R., Kirkwood, D., Midgley, J. \& Pierce, S. 1997. Invasion and persistence of bird-dispersed, subtropical thicket and forest species in fire-prone coastal fynbos. J. Veg. Sci. 8: 475-488.

Cowling, R., Richardson, D. \& Paterson-Jones, C. 1995. Fynbos - South Africa's Unique Floral Kingdom. Western Cape: Fernwood Press.

Dennis, A.J. \& Westcott, D.A. 2006. Reducing complexity when studying seed dispersal at community scales: a functional classification of vertebrate seed dispersers in tropical forests. Oecologia 149: 620-634.

Fricke, E.C., Simon, M.J., Reagan, K.M., Levey, D.J., Riffell, J.A., Carlo, T.A. \& Tewksbury, J.J. 2013. When condition trumps location: seed consumption by fruit-eating birds removes pathogens and predator attractants. Ecol. Lett. 16: 1031-1036.

Fritz, J., Kienzle, E., Hummel, J., Wings, O., Streich, W.J. \& Clauss, M. 2011. Gizzard vs. teeth, it's a tie: foodprocessing efficiency in herbivorous birds and mammals and implications for dinosaur feeding strategies. Paleobiology 37: 577-586.

Glyphis, J.P., Milton, S.J. \& Siegfried, W.R. 1981. Dispersal of Acacia cyclops by birds. Oecologia 48: 138-141.

Henderson, L. 2001. Alien Weeds and Invasive Plants - $A$ Complete Guide to Declared Weeds and Invaders in South Africa. Plant Protection Research Institute Hand Book, Vol. 12th. Pretoria: Agricultural Research Council.

Higgins, S.I., Nathan, R. \& Cain, M.L. 2003. Are longdistance dispersal events in plants usually caused by nonstandard means of dispersal? Ecology 84: 1945-1956.

Hockey, P.A.R., Dean, W.R.J. \& Ryan, P.G. (eds) 2005. Roberts' Birds of Southern Africa, 7th edn. Cape Town: John Voelcker Bird Book Fund.

Holmes, P.M. 1990. Dispersal and predation of alien Acacia seeds: effects of season and invading stand density. S. Afr. J. Bot. 56: 428-434.

Howe, H.F. \& Smallwood, P.D. 1982. Ecology of seed dispersal. Annu. Rev. Ecol. Syst. 13: 201-228.

Hulme, P. \& Benkman, C.W. 2002. Granivory. In Herrera, C. \& Pellmyr, O. (eds) Plant-Animal Interactions: An Evolutionary Approach: 185-208. New York: Blackwell Scientific Publications.
Impson, F.A.C. 2005. Biological control of Acacia cyclops in South Africa: the role of an introduced seedfeeding weevil, Melanterius servulus (Coleoptera: Curculionidae) together with indigenous seed-sucking bugs and birds. M.Sc. Thesis, University of Cape Town.

Impson, F., Hoffmann, J.H. \& Kleinjan, C. 2009. Australian Acacia species (Mimosaceae) in South Africa. In Muniappan, R., Reddy, G.V. \& Raman, A. (eds) Biological Control of Tropical Weeds Using Arthropods: 38-62. Cambridge: Cambridge University Press.

Impson, F.A.C., Kleinjan, C.A., Hoffmann, J.H., Post, J.A. \& Wood, A.R. 2011. Biological control of Australian Acacia species and Paraserianthes lophantha (Willd.) Nielsen (Mimosaceae) in South Africa. Afr. Entomol. 19: 186-207.

Jordaan, L.A., Johnson, S.D. \& Downs, C.T. 2011. The role of avian frugivores in germination of seeds of fleshy-fruited invasive alien plants. Biol. Invasions 13: 1917-1930.

Jordano, P. 2000. Fruits and frugivory. In Fenner, M. (ed.) Seeds: The Ecology of Regeneration in Natural Plant Communities: 125-166. Wallingford: CABI Publishers.

Knight, R.S. 1988. Aspects of plant dispersal in the southwestern Cape with particular reference to the roles of birds as dispersal agents. PhD dissertation, University of Cape Town.

LaFleur, N., Rubega, M. \& Parent, J. 2009. Does frugivory by European Starlings (Sturnus vulgaris) facilitate germination in invasive plants? J. Torrey Bot. Soc. 136: 332-341.

Lambert, F.R. 1989. Pigeons as seed predators and dispersers of figs in a Malaysian lowland forest. Ibis 131: 521-527.

Lopez-Colleja, M. \& Bozinovic, V.F. 2000. Ecología energética y nutricional en aves herbívoras pequeñas. Rev. Chil. Hist. Nat. 73: 411-420.

Manders, P.T. \& Richardson, D.M. 1992. Colonization of Cape fynbos communities by forest species. For. Ecol. Manage. 48: 277-293.

Midgley, J.J. \& Anderson, B.C. 2005. Scatterhoarding in Cape fynbos. In Forget, P.-M. (ed.) Seed Fate: Predation, Dispersal and Seedling Establishment. 197-204. Wallingford: Ciba Publishing.

Milton, S.J. \& Hall, A.V. 1981. Reproductive biology of the Australian acacias in the southwestern Cape Province, South Africa. Trans. R. Soc. S. Afr. 44: 465-485.

Mokotjomela, T.M. 2012. A comparison of bird foraging preferences for fruits of indigenous and alien shrubs and seed dispersal potentials in the Cape Floristic Region. Ph.D. Thesis, Stellenbosch University.

Mokotjomela, T.M. \& Hoffmann, J.H. 2013. Removal of postdispersed seeds in Acacia cyclops thickets under biological control in South Africa. S. Afr. J. Bot. 88: 260-264.

Mokotjomela, T., Musil, C. \& Esler, K.J. 2013a. Potential seed dispersal distances of native and non-native fleshy fruiting shrubs in the South African Mediterranean climate region. Plant Ecol. 214: 1127-1137.

Mokotjomela, T.M., Musil, C.F. \& Esler, K.J. 2013b. Do frugivorous birds concentrate their foraging activities on those alien plants with the most abundant and nutritious fruits in the South African Mediterranean-climate region? Plant Ecol. 214: 49-59.

Mokotjomela, T., Musil, C. \& Esler, K. 2015. An appraisal of seed enumeration and videographic techniques for determining seed removal rates by birds. Afr. J. Ecol. doi: 10.1111/aje.12201. http://onlinelibrary.wiley.com/doi/10.1111/ aje.12201/abstract 
Moran, V., Hoffmann, J. \& Zimmermann, H. 2013. 100 years of biological control of invasive alien plants in South Africa: history, practice and achievements. S. Afr. J. Sci. 109: 1-6.

Murray, B. \& Phillips, M. 2010. Investment in seed dispersal structures is linked to invasiveness in exotic plant species of south-eastern Australia. Biol. Invasions 12: 2265-2275.

Nathan, R. 2001. The challenges of studying dispersal. Trends Ecol. Evol. 16: 481-483.

Nathan, R. 2007. Total dispersal kernels and the evaluation of diversity and similarity in complex dispersal systems. In Dennis, A.J., Schupp, E.W., Green, R.J. \& Westcott, D.A. (eds) Seed Dispersal: Theory and its Application in a Changing World: 252-266. Reading: Biddles Ltd.

Nathan, R., Schurr, F.M., Spiegel, O., Steinitz, O., Trakhtenbrot, A. \& Tsoar, A. 2008. Mechanisms of longdistance seed dispersal. Trends Ecol. Evol. 23: 638-647.

Nel, J.L., Richardson, D.M., Rouget, M., Mgidi, T.N., Mdzeke, N., le Maitre, D.C., van Wilgen, B.W., Schonegevel, L., Henderson, L. \& Neser, S. 2004. A proposed classification of invasive alien plant species in South Africa: towards prioritizing species and areas for management action. S. Afr. J. Sci. 100: 53-64.

Pratt, K.T. \& Stiles, W.E. 1983. How long fruit-eating birds stay in the plants where they feed: implications for seed dispersal. Amer. Nat. 122: 797-805.

Richardson, D.M., Macdonald, I.A.W., Holmes, P.M. \& Cowling, R.M. 1992. Plant and animal invasions. In Cowling, R.M. (ed.) The Ecology of Fynbos: Nutrients, Fire and Diversity: 271-308. Cape Town: Oxford University Press.

Richardson, D.M., Carruthers, J., Hui, C., Impson, F.A.C., Miller, J.T., Robertson, M.P., Rouget, M., Le Roux, J.J. \& Wilson, J.R.U. 2011. Human-mediated introductions of Australian acacias - a global experiment in biogeography. Divers. Distrib. 17: 771-787.

Rogers, A. \& Chown, S. 2014. Novel ecosystems support substantial avian assemblages: the case of invasive alien Acacia thickets. Divers. Distrib. 20: 34-45.

Rusch, U.D. 2011. Scatter-hoarding in Acomys subspinosus: the roles of seed traits, seasonality and cache retrieval. MSc Thesis, Stellenbosch University.

Sakai, A.K., Weller, S.G., Allendorf, F.W., Holt, J.S., Lodge, D.M., Molofsky, J., With, K.A., Baughman, S., Cabin, R.J., Cohen, J.E., Ellstrand, N.C., McCauley, D.E., O'Neil, P., Parker, I.M. \& Thompson, J.N. 2001. The population biology of invasive species. Annu. Rev. Ecol. Syst. 32: 305-332.

Saracco, J., Collazo, J., Groom, M. \& Carlo, T. 2005. Crop size and fruit neighborhood effects on bird visitation to fruiting Schefflera morototoni trees in Puerto Rico. Biotropica 37: 81-87.

Schaefer, H.M. \& Schaefer, V. 2006. The fruits of selectivity how birds forage on Goupia glabra fruits. J. Ornithol. 147: 638-643.

Schaefer, H.M., Schmidt, V. \& Bairlein, F. 2003. Discrimination abilities for the main nutrients - which difference matters for choosy birds? Anim. Behav. 65: 531-541.

Schupp, E.W. 1993. Quantity, quality and the effectiveness of seed dispersal by animals. Vegetatio 107/108: 15-29.
Schupp, E.W., Jordano, P. \& Gomez, J.M. 2010. Seed dispersal effectiveness revisited: a conceptual review. New Phytol. 188: 333-353.

Schurr, F.M., Spiegel, O., Steinitzm, O., Trakhtenbrot, A., Tsoar, A. \& Nathan, N. 2009. Long-distance seed dispersal. Annu. Plant Rev. 38: 204-237.

Scott, J.K. \& Batchelor, K.L. 2014. Management of Chrysanthemoides monilifera subsp. rotundata in Western Australia. Invasive Plant Sci. Manag. 7: 190-196.

Shaughnessy, G.L. 1980. Historical ecology of alien woody plants in the vicinity of Cape Town, South Africa. Ph.D. Thesis, University of Cape Town.

Spiegel, O. \& Nathan, R. 2007. Incorporating dispersal distance into the disperser effectiveness framework: frugivorous birds provide complementary dispersal to plants in a patchy environment. Ecol. Lett. 10: 718-728.

Stevens, C.E. \& Hume, I.D. 1998. Contributions of microbes in vertebrate gastrointestinal tract to production and conservation of nutrients. Physiol. Rev. 78: 393-427.

Tame, T. 1992. Acacias of Southeast Australia. Sydney: Kangaroo Press.

Traveset, A. 1998. Effect of seed passage through vertebrate frugivores' guts on germination: a review. Perspect. Plant Ecol. Evol. Syst. 1: 151-190.

Traveset, A., Riera, N. \& Mas, R.E. 2001. Passage through bird guts causes interspecific differences in seed germination characteristics. Funct. Ecol. 15: 669-675.

Tsoar, A., Shohami, D. \& Nathan, R. 2011. A movement ecology approach to study seed dispersal and plant invasion: an overview and application of seed dispersal by fruit bats. In Richardson, D.M. (ed.) Fifty Years of Invasion Ecology. The Legacy of Charles Elton: 103-119. Oxford: Wiley-Blackwell.

Tucker, K.C. \& Richardson, D.M. 1995. An expert system for screening potentially invasive alien plants in South African fynbos. J. Environ. Manage. 44: 309-338.

Underhill, G.L. \& Hofmeyr, H.J. 2007. Barn Swallows Hirundo rustica disperse seeds of rooikrans Acacia cyclops, an invasive alien plant in the fynbos biome. Ibis 149: 468-471.

Van Der Pijl, L. 1982. Principles of Dispersal in Higher Plants, Vol. 3. Berlin: Springer.

Van Wilgen, B.W., Dye, C., Hoffmann, J.H., Philip Ivey, P., Le Maitre, D.C., Moore, J., Richardson, D.M., Rouget, M., Wannenburgh, A. \& Wilson, J.R.U. 2011. National-scale strategic approaches for managing introduced plants: insights from Australian acacias in South Africa. Divers. Distrib. 17: 1060-1075.

Wang, B.C. \& Smith, T.B. 2002. Closing the seed dispersal loop. Trends Ecol. Evol. 17: 379-386.

Willson, M.F. \& Whelan, C.J. 1993. Variation of dispersal phenology in a bird-dispersed shrub, Cornus drummondii. Ecol. Monogr. 63: 151-172.

Received 9 June 2014; revision accepted 14 March 2015. Associate Editor: Robert Fletcher. 